\title{
GRANITIC PEGMATITES OF KORADI-KOLAR SECTOR, NAGPUR DISTRICT, CENTRAL INDIA: FIELD, PETROGRAPHIC AND MINERALOGICAL FEATURES
}

\author{
L.G. GWALANI*, V.P.DALAL**, SOLEDAD FERNÁNDEZS.*** B.P. MULAI**** , SHIREEN PARVEEN**** \\ AND B.V.SHASTRY*
}

\begin{abstract}
Several bodies of pegmatites have been located within the rocks of Sausar Group (Precambrian) occurring in the Kolar valley, north of Koradi, in Nagpur district of Central India. The XRD and the chemical data have shown that these pegmatites are mostly potassic $\left(\mathrm{K}_{2} \mathrm{O}=15.58\right.$ to $16.31 \%$ and $\mathrm{Na}_{2} \mathrm{O}=2.50$ to $\left.3.12 \%\right)$ and are barren of economic mineral deposits. The pegmatites range from a few cm to more than $50 \mathrm{~m}$ in width with a maximum extension of about one kilometre. Several mappable pegmatite bodies trend roughly EW and NS, and many good outcrops are encountered in the Kolar Valley and Suradevi Hills. Based on the field and petrographic studies, the pegmatites of this area are characterised in terms of size, shape and mode of emplacement. They are mostly tabular, lenticular, branching and irregular bodies, localised along bedding, foliation, fault planes, tension joints and fold axis. Structurally they can be subdivided into concordant and discordant types on the basis of their relationship with the country rocks. Mineralogically, pegmatites are grouped into (1) Simple Pegmatite, containing quartz, feldspar, biotite, apatite, garnet and (?) monazite, and (2) Complex Pegmatite comprising in addition muscovite, tourmaline and epidote. However, common mineral variation is observed at different places within the same body of pegmatite. In these pegmatites, muscovite, quartz, tourmaline and feldspar seem to have developed mainly in two distinct generations, for example, the muscovite of earlier generation forms tiny "books" while later crystals occur as small disseminated flakes in the groundmass of less coarser quartz. The earlier quartz is strongly deformed, while the later occurs as veins of variable dimensions. The black tourmaline of earlier generation is represented by schorlite and of later origin has been identified as dravite. It may be concluded that these pegmatites were formed by the influx of fluids rich in silica, $\mathrm{Al}$ and $\mathrm{K}$ that filled the fractures and other planes of weakness (foliation) in the host rocks. The alkali components while migrating towards the wall of the country rocks, crystallised as muscovite and feldspar. In larger pegmatite bodies of Suradevi Hills, the development and concentration of muscovite along their contact with the mica schist is probably due to the migration of $\mathrm{Al}$ and $\mathrm{K}$ and volatiles towards the border of the intrusion. This crystallization of muscovite in preference to potash-feldspar may be due to the presence of high contents of volatiles.

Key words: Central India, pegmatites, classification, mineral chemistry, XRD data, genesis
\end{abstract}

INTRODUCTION The extensive belts of pegmatites in India of Precambrian age are those of the three mica-producing fields of Bihar, Rajasthan and Nellore (Babu 1969, Bhola 1971, Datta 1973). The Bastar-Koraput belt of Madhya Pradesh and Orissa is well known for its rare met al (Sn, Ta, Be and $\mathrm{Li}$ ) bearing minerals, such as cassiterite, columbite, tantalite, beryl, lepidolite, amblygonite, etc. (Ramaswamy et al 1976, Lamba and Khanna 1981, Babu 1993). These pegmatite belts are localised in metamorphic terrains and are generally associated with granitic rocks. Pegmatites are also common in the Sausar Group of Chhindwara and Nagpur districts of central India ( West 1933, Fermor 1936).

At a distance of about $15 \mathrm{~km}$ to the north of the city of Nagpur, the pegmatites of Koradi-Kolar Valley are localised in highly deformed Precambrian rocks of the Sausar Group. Unlike the aforesaid four major belts, the pegmatites of the present area neither contain commercial mica nor rare met al deposits. They occur as large solitary bodies or in swarms of minor intrusives (dykes, sills and veins) extending from west of Koradi Mata Temple to the east of Suradevi Hills (Latitude: $21^{\circ} 20^{\prime} \mathrm{N}$ and Longitude: $79^{\circ} 7^{\prime} \mathrm{E}$, Survey of India Toposheet Nos. 55: 0/3 \& 0/4).

Except for a few published papers (Kilpady 1954, Gwalani et al. 1997), no significant literature is available on the pegmatites of this area. The present work includes new geological map of the area (Fig. 1 ), and preliminary evaluation of about 15 major outcrops of pegmatites. An attempt has been made to describe their field, petrographic and mineralogical features.

GEOLOGICAL SETTING Geology of Koradi-Kolar Valley is presented in Fig. 1, and a summary of rock types encountered is given in Table 1. The Precambrian rocks exposed in this sector belong to the Sausar Group comprising metasedimentary and metabasic rocks, which are at places profusely intruded by acidic phases (pegmatites, quartz veins and gneissic granite/orthogneiss) (Gwalani \& Dalai 1988). The upper part of the Sausar Group sequence of rock Formations consists of (from the older to the younger): Chorbaoli Formation (quartzites and associated quartz-mica schist); Jenewani Formation (muscovite- biotite schist), and Bichua Formation (mostly dolomitic marbles), meta-amphibolites, orthogneiss/ gneissic granite and pegmatites and quartz veins.

In the neighbouring districts of Bhandara and Drug, the K-Ar ages of muscovite and biotite from the schists (Sausar Group) have indicated that the regional metamorphism and granitization had closed during the period 244-996 million years ago (Sarkar et al. 1967). The sequence of rocks (Table 1), which is the extension of the type Sausar area (Kumar 1992), observed in this sector are described below in relation to their structural characteristics favourable for pegmatite emplacement.
Quartzites and Schists (Chorbaoli and Junewani Formations) Mica-schist is an important rock for the pegmatite emplacement. The rock shows well-developed schistosity and multiple sets of joints. At places, the schist is interbedded with quartzite bands of variable thickness, size and extent. The thickly bedded quartzite is not favourable locale for the pegmatite emplacement. However, along the contact of mica-schist and quartzite, the concordant pegmatite intrusions are observed (e.g. Western Suradevi Hills).

Dolomitic Marbles (Bichua Formation) Marbles occur as scattered outcrops (bedded or massive) and they range in colour (white to dirty white to light greenish), texture (fine- to coarse sacchroidal) and mineralogy. They are mostly dolomitic containing tremolite, actinolite, calcite, serpentine etc. At places, near the contact with pegmatite, the marbles show baking effects and superficial patches of hard pegmatitic material that stands out from the weathered surface of a comparatively softer marble.

Amphibolites and Streaky Gneisses The amphibolites are emplaced by many aplitic and pegmatitic bodies. These intrusive bodies cut across and also occur within the planes of schistosity of amphibolites (Figs. 2-A and B). These amphibolites appear banded due to aplitic layers of roughly about a centimetre thick, and often, in about one metre of thickness, there occur at least 20 aplitic layers. This composite rock with banded appearance have been termed streakygneiss (West 1933, Fermor 1936).

Gneissic Granite/Orthogneiss Outcrops of gneissic granite (orthogneiss) have limited aerial extent and are seen prominently in the Kolar Valley (e.g. near Chhindwara road) where they are closely associated with amphibolites, marbles and schists. But the pegmatites have emplaced within the orthogneiss and amphibolites. The rock generally has shades of pinkish white to reddish brown colour owing to abundant presence of K-feldspar (microcline). In the Kanhan river, near the railway bridge, the coarse granitic gneiss is exposed. It comprises feldspar, quartz and black mafic minerals (biotite and hornblende).

PEGMATITES Field Characteristics Haidenger (1845) and many later workers used the term "pegmatite" for describing very coarse-grained feldspar-rich granites. Throughout this paper the term pegmatite usually means granitic pegmatites unless otherwise specified.

Mode of Emplacement The emplacement of pegmatites without the development of apophyses in the wall rocks, indicate the smooth flowage of pegmatite magma through the available planes of weakness (schistosity, tension joints, fold-axis and fault planes) in the country rocks. Structural control of the emplacement of a few pegmatite sills

* $\quad$ N.U. Geology Dept., C/O C-1 Neel Kamal, 2-Hasnabad, Santacruz West, Mumbai (Bombay) 400 054, India

** Water Resources Engineers, Department of Environment, Baltimore, Md, 21224, USA

*** Depto. Petrologia y Geoquimica, Faculdad Ciencias Geologicas, UCM, 28040, Madrid, Spain

**** Dept. of Geology, NU, P.O. Box 470, Shankar Nagar P.O., Nagpur 440010 , India

***** Dept. of Civil Engineering, Visvesvaraya Regional College of Engineering, Nagpur-440011, India. 


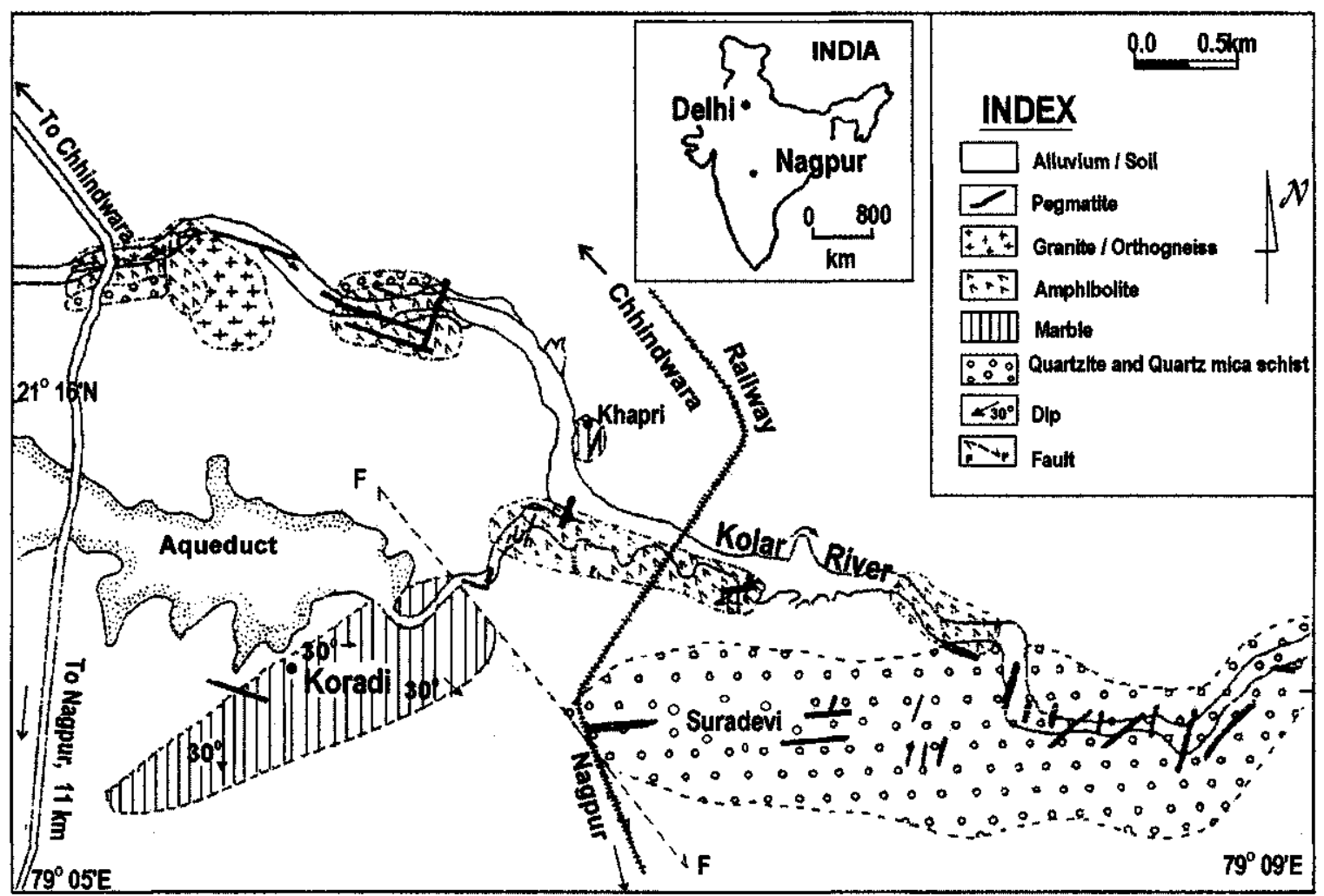

Figure 1 - Reconnaisance geological-map of Koradi-Kolar sector, north of Nagpur, central India (modified after Gwalani et al, 1997). Note that a few outcrops of the country rocks and pegmatites are slightly exaggerated in their dimensions for the convenience of plotting. There are many minor intrusions of pegmatite not shown in this map. Inset map shows locality of Nagpur in central India.

was afforded by contacts between dissimilar rock types, as for example between quartzite and quartz-mica schist in Suradevi Hill and between biotite-scnist and amphibolite in Kolar Valley. Such concordant pegmatites may show a marked gradational contact and contain partly digested rock inclusions (Fig.SA) which indicate that the emplacement was effected by replacement of country rock. Ptygmatic folding observed at a few places is due to deformation (migmatization) and not because of infilling of tortuous fractures by pegmatitic (aplite) melt in the amphibolite.

Wall Rock Alteration The pegmatites usually have sharp contact with the host rocks but are in places separated by a narrow zone of wall rock alteration. The alteration involves development of new minerals, such as tourmaline and epidote, and recrystallization of mica, and also silicification of wall rocks. Tourmalinization of wall rock (e.g. amphibolite) has lead to the formation of tourmaline-rich cluster with schistose structure along the wall rock, even when the pegmatites are completely devoid or contain sparse tourmaline.

The nature and extent of wall rock alteration mainly depends upon mineralogical composition of wall rock and the attitude of the pegmatite body. The alteration is well observed along the concordant pegmatites which have been emplaced in foliated rocks (e.g. southern bank of Kolar river), which facilitates permeation and flow of fluids along the planes of foliation.

Size and Shape The pegmatites show wide variation in size and shape. They mostly are tabular or long and narrow sinuous bodies intermittently disappearing under the soil cover, others are branching and irregular. Thus, they vary from insignificant stringers to bodies about one kilometre in length and more than $15 \mathrm{~m}$ in width. The size and shape of pegmatites are controlled .by structure and nature of the rock into which they have been emplaced. Many pegmatite bodies are parallel to sub-parallel to the bedding and foliation in the schistose country rock (mica-schist and amphibolite). Some pegmatites deviate from such concordant attitude and cut across the bedding and foliation in the country rocks (orthogneiss and quartzite).

Structural Classification Classifications of Indian pegmatites are predominantly based on form, size, and relationship with the host rock, texture and internal structure (e.g. Datta 1973), mineral and chemical composition (e.g. Babu 1969), mode of development (e.g. Soman \& Nair 1986, Singh \& Sharma 1997); and mineral paragenesis and rare met al mineralization (e.g. Babu 1963), etc. With reference to the structural relationship with the host rocks, the pegmatites of KoradiKolar sector are broadly distinguished as concordant and discordant types. However, they can be also sub-divided on the basis of their texture and mineralogy as described in the next section.

CONCORDANT PEGMATITES Pegmatites concordant with the bedding and foliation generally show tabular and lenticular form. Though they follow the structure of the host rock, they show variation in dip $\left(55^{\circ}\right.$ to $\left.90^{\circ}\right)$ and strike (trend) which correspond to the structural deviation observed in the host rocks. At many places the tabular sheets of pegmatites are emplaced concordantly within the planes of schistosity of amphibolites to form banded or "streaky" gneiss (Fig. 2-B). Lenticular pegmatites are broader but gradually pinch out either at one end or at both the ends.

DISCORDANT PEGMATITES Although the pegmatitic injections follow the bedding or foliation of the pre-existing host rocks; at many places, they generally follow joint planes that cut sharply across the bedding and foliation (Fig. 2a). Such pegmatites at times show branching pattern with irregular margins, or they occur as dykes exhibiting a narrow and straight course with regular margins. Branching pegmatites (e.g. in a major tributary of the Kolar river) often exhibit a number of small concordant offshoots (apophyses) from the larger discordant body hosted in the amphibolites possessing well developed schistose structure. In the eastern part of Suradevi Hill range, the quarry section shows a series of almost vertical pegmatite dykes in micaceous quartzites (Fig. 3B).

Petrographic Features Many pegmatites of the studied area exhibit more or less uniform texture and mineralogy from wall to wall and along their entire length. They are medium $(2.5$ to $10 \mathrm{~cm})$ to coarse (10 to $30 \mathrm{~cm}$ ) grained (Cameron et al 1949), and mainly composed of quartz, K- feldspar, muscovite and tourmaline with variable accessory minerals such as biotite and epidote. On the basis of mineralogical variations, the pegmatites of this sector may be classified into: 
Table 1 - Summary of Sausar rocks present (metasedimentary, metabasics and associated acid intrusions) within the Koradi-Kolar sector of the Nagpur Disctrict, India.

\begin{tabular}{|c|c|c|c|}
\hline $\begin{array}{l}\text { Lociality } \\
\text { (examples) }\end{array}$ & $\begin{array}{l}\text { Rock typef } \\
\text { Formation }\end{array}$ & Field characteristics & Mineralogy \\
\hline $\begin{array}{l}\text { Kolar, souihern } \\
\text { tank }\end{array}$ & \multirow[t]{2}{*}{$\begin{array}{l}\text { Peganatite fyounger } \\
\text { acid intrusive } \\
\text { rocks) }\end{array}$} & 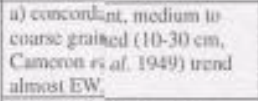 & 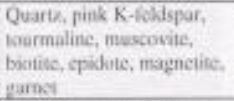 \\
\hline $\begin{array}{l}\text { Koridh, } \\
\text { Surabevi Hill, } \\
\text { Kolar and its } \\
\text { main enibutary }\end{array}$ & & 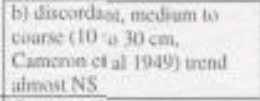 & $\begin{array}{l}\text { Qvartx, pink microcline, } \\
\text { muscovite, tourmaline, } \\
\text { maggetice }\end{array}$ \\
\hline $\begin{array}{l}\text { Kilar river, } \\
\text { nontherm bank }\end{array}$ & 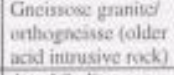 & $\begin{array}{l}\text { Coarses and wendly } \\
\text { gncissosc, :pheroudal } \\
\text { wcielerenge }\end{array}$ & $\begin{array}{l}\text { Micrucline, quartz, sodic } \\
\text { plagioclass, bivene. } \\
\text { magnetile, riinton }\end{array}$ \\
\hline Kolar nuser & \begin{tabular}{|l|} 
Amplathotisc \\
(meabusis roeks)
\end{tabular} & 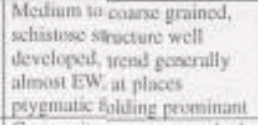 & 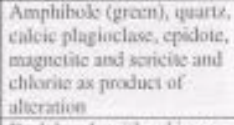 \\
\hline $\begin{array}{l}\text { Kowar ans ins } \\
\text { major tributany }\end{array}$ & 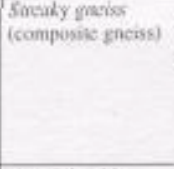 & 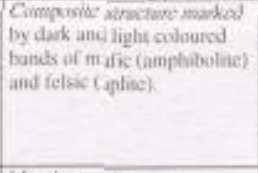 & 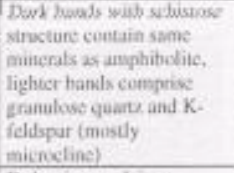 \\
\hline Koraati & $\begin{array}{l}\text { a) aphicalcile - } \\
\text { Bichua } \\
\text { Finmation }\end{array}$ & 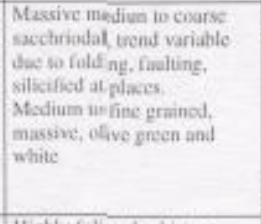 & $\begin{array}{l}\text { Gresen sopentine and white } \\
\text { calcie }\end{array}$ \\
\hline Kondi \& Kolar & $\begin{array}{l}\text { Mluscovie bistise } \\
\text { scbist-Janewani } \\
\text { Formalive } \\
\end{array}$ & $\begin{array}{l}\text { Highty foll ned schistose } \\
\text { siructure, fencrilly showing } \\
\text { EW ueadls }\end{array}$ & $\begin{array}{l}\text { Muscionic, bintie with } \\
\text { minor flatspar } \pm \text { qearts }\end{array}$ \\
\hline Surndevifitils & $\begin{array}{l}\text { Quartxile and } \\
\text { quante micaschist - } \\
\text { Cluihaali } \\
\text { Formation }\end{array}$ & 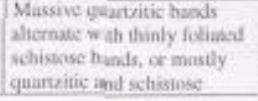 & $\begin{array}{l}\text { Qualk, Hascovite, } \\
\text { Felakpar = tousnaline, } \\
\text { minor magpetite }\end{array}$ \\
\hline
\end{tabular}

i) Simple: Consisting of quartz, feldspar, biotite and apatite, and

ii) Complex: Containing in addition muscovite, tourmaline and epidote.

Graphic intergrowths of quartz and feldspar (Fig. 4A), and tourmaline and quartz are also characteristics of complex pegmatites. Based on the dominant mineral content, the Koradi-Kolar pegmatites can be distinguished as quartz-rich and feldspar-rich pegmatites. Considering the mineralogical association observed, we have classified these pegmatites into the following types: - (a) Microcline-Quartz-Muscovite Pegmatite, (b) Tourmaline-Quartz with or without Feldspar and Mica, (c) Quartz-Muscovite Pegmatite, (d) Eutectic Quartz and Microcline (Graphic granite /Runite). (e) Massive Quartz Pegmatite. The petrographic characteristics of each of the above 5 types of variations are described in the next paragraphs.

MICROCLINE-QUARTZ-MUSCOVITE PEGMATITE This unit comprises microcline, which is generally pink in colour and occurs either as (a) large blocks present in the groundmass of quartz aggregates and muscovite, or as (b) large crystals interlocked with quartz. The concentration of giant feldspar phenocrysts (large blocks of microcline) is so much that in patches these larger pegmatitic bodies appear as monomineralic rock. The feldspar patches are invariably surrounded by comparatively finer aggregates of a quartz $(+$ muscovite). These pegmatites have sharp contacts with the country rocks (orthogneiss and amphibolites).

TOURMALINE-QUARTZ WITH OR WITHOUT FELDSPAR AND $M I C A$ This unit range in composition from dominant quartz and tourmaline ( \pm mica) to dominant microcline and tourmaline $( \pm$ mica). The black striated tourmaline occurs as solitary ditrigonal crystals, or branching crystals or as clusters of radiating finer needles and coarser columns in the extensive concordant bodies of pegmatite in Kolar valley (Fig. 4B). Many of the larger crystals of tourmaline, identified as schorlite and dravite (Kilpady 1954), have been deformed by stresses induced during post-tourmaline formation. Such crystals are often curved and show a large number of closely spaced transverse fractures (Fig. 5). Tourmaline crystals as large as 10 to $15 \mathrm{~cm}$ in length with a diameter of $5 \mathrm{~cm}$ have been recorded from these pegmatites (Kilpady 1954).

Five different mineral association observed in this unit are: (a) Quartz and Tourmaline, (b) Microcline and Tourmaline, (c) Quartz Tourmaline and Microcline. (d) Muscovite and Tourmaline ( \pm Quartz) (e) Tourmaline and Biotite ( \pm Muscovite and Quartz).

Inclusion of one or more minerals such as feldspar, biotite and muscovite (Fig. 5) are often noticed in the tourmaline crystals.

QUARTZ AND MUSCOVITE This unit almost entirely comprises massive, milky white or colourless quartz and flaky aggregates of muscovite. Quartz generally occurs as sutured or coarse aggregates of anhedral grains. This type of pegmatites is generally encountered in amphibolites and metasedimentary rock. These pegmatites are emplaced at the contact of quartz-mica schist and amphibolite at a few places in the Kolar valley. In Suradevi Hills, they are seen along the quartz-muscovite schist and quartzite contact.

EUTECTIC QUARTZ AND MICROCLINE (GRAPHIC GRANITE/RUNITE) This unit is almost entirely composed of quartz and microcline. The minerals show typical graphic texture (Fig 4A). Such pegmatitic bodies occur as minor intrusions (e.g. in a major tributary of Kolar River) or are seen as patches in the larger pegmatites rich in quartz and feldspar. This unit also shows sharp contact with the country rocks.

MASSIVE QUARTZ PEGMATITE It generally consists of milky white quartz and occasionally encloses mica and tourmaline, and when these minerals are present, they are confined to the margin of the quartz
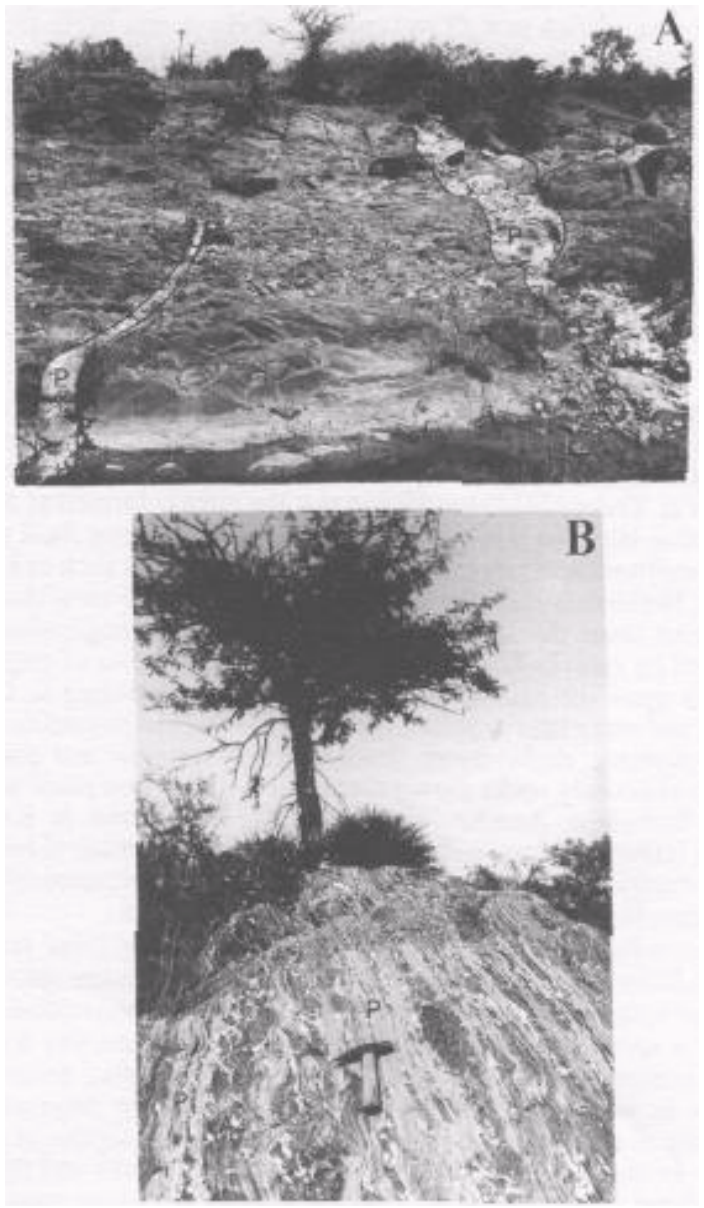

Figure 2 - (a) - Small fracture controlled discordant pegmatite $(P)$ bodies in amphibolite (A) exposed in a major tributary of the Kolar river, northeast Koradi. (b) -Amphibolite (A) intimately and concordantly penetrated by aplite-pegmatite $(P)$ to form composite streaky gneiss exhibiting light and dark bands. The resistant lighter leucocratic bands of aplitic material stand out due to differential weathering of comparatively softer amphibolite bands. 
body. The quartz-pegmatites also occur as veins within the other pegmatite units and the country rocks. They show sharp contact with host rocks and generally occupy irregular fractures in the pegmatite units and gneissose granite.

Mineralogical Features $X-R A Y$ DIFFRACTION STUDIES The X-ray Diffraction profile of the pegmatites from Kolar valley was obtained by using Phillips PW1840 X-ray generator system operated at $30 \mathrm{kV}$ and $20 \mathrm{~mA}$ with $\mathrm{Cu}(\mathrm{K} \alpha)$ radiation. The sample was scanned between $4^{\circ}$ to $43^{\circ}, 2$-lheta $(\theta)$ range with $1^{\circ}, 2$ theta $(\theta)$ per minute scanning speed. The peak angles and spacings obtained were compared with the values compiled in the KWIC Guide to the Powder Diffraction File data records published by the American Society for Testing and Material (ASTM) and by Joint committee on Powder Diffraction Standards (JCPDS) (1974). The XRD Diffraction Tables (1954) published by Feffir and Simons, Inc. London/Amsterdam were also used during this investigation.

The diffraction patterns of the feldspar-rich pegmatite from the Kolar valley are given in Fig. 6 and interplannar spacings ('d') and 'hkl' or mineral indices number, along with mineral names are given in Table 2. The X-ray diffraction (XRD) studies have revealed that the dominant minerals of the Kolar Valley pegmatites include potash-feldspars (mostly microcline and some orthoclase) and illite along with accessory ilmenite and magnetite.

MINERAL CHEMISTRY Samples of pink feldspar (microcline) and muscovite were analysed by modern techniques (Gwalani et al. 1993) in the chemical laboratories of Universidad Complutence de Madrid (UCM), Spain. The results are presented in Table 3 along with an analysis of microcline microperthite from Bihar mica-belt, India reported by Deer et al (1963). Both microcline and muscovite of the present area are rich in $\mathrm{K}_{2} \mathrm{O}$ and comparatively poorer in $\mathrm{Na}_{2} \mathrm{O}$. In the feldspar samples, the $\mathrm{K}_{2} \mathrm{O}$ content varies between $15.80 \%$ to $16.31 \%$ and in muscovite it is $11.34 \%$ which clearly indicate that the pegmatites of the present area are potassic in nature, and perhaps they are even more potassic than the pegmatites of Bihar mica-belt. The microcline microperthite from Bihar is comparatively low in $\mathrm{K}_{2} \mathrm{O}$ content $(13.2 \%)$ but shows similarity in the $\mathrm{Na}_{2} \mathrm{O}$ values (Table 3 ).

GENESIS OF MICA AND TOURMALINE Muscovite and tourmaline occur as important components of a few pegmatites of this area; each of these minerals appear to be of different origin as described below:

Genesis of Muscovite According to Cameron et al. (1949), mica is derived by direct crystallisation from pegmatitic magma rich in $\mathrm{Na}_{2} \mathrm{O}, \mathrm{K}_{2} \mathrm{O}, \mathrm{Al}_{2} \mathrm{O}_{3}, \mathrm{SiO}_{2}$, and volatiles. Experimental work of Eugster \& Yoder (1954) has shown that the mica is formed as a result of reaction between potash feldspar and the co-existing fluid during the crystallisation of pegmatite. Many earlier workers such as Landes (1933), Holland (1902), Biswas (1929) supported the view that mica is formed from the assimilation of rocks by the pegmatitic melt followed by recrystallization, and that the mica content of pegmatite depends upon the nature of the country rock. According to Galpin (1918) and other later workers, the origin of mica in pegmatite is due to metasomatic replacement (hydrothermal solution and pneumatolysis) of country rocks during the post-crystallisation phase of pegmatite formation. Another view suggested by Quirke \& Kramers (1943), is that a post crystallisation hydrothermal alteration of feldspar, which results in the replacement of $\mathrm{Si}$ by $\mathrm{Al}$ and accommodation of $(\mathrm{OH})$ ions, in pegmatite can lead to formation of mica.

Muscovite in pegmatite occurs in all the petrographic types of Koradi-Kolar sector, except in the units comprising quartz-microcline feldspar with a graphic texture and massive quartz-tourmaline. Muscovite is seen as disseminated flakes and small books and does not form commercial lodes in these pegmatites. It is either absent or is present in negligible amount in the potash-feldspar pegmatites. It generally occurs in the pods containing granular aggregates of coarse quartz. In Suradevi Hill range muscovite as tiny books and disseminated flakes usually occur in larger concentration near the mica-schist wall. The presence of comparatively more muscovite in the wall rock mica-schist is probably the result of recrystallization of country rocks under the influence of pegmatitic fluids (Cameron et al. 1949). However, the sharp contact of the country rock with many pegmatites does support a purely magmatic origin of mica in pegmatite. The earliest solution may have been silica rich and appear to have had varying contents of alkalis and alumina, resulting in the formation of a massive quartz body on the one hand, and muscovite-quartz-pegmatite on the other hand. The presence of such contrasting mineral composition
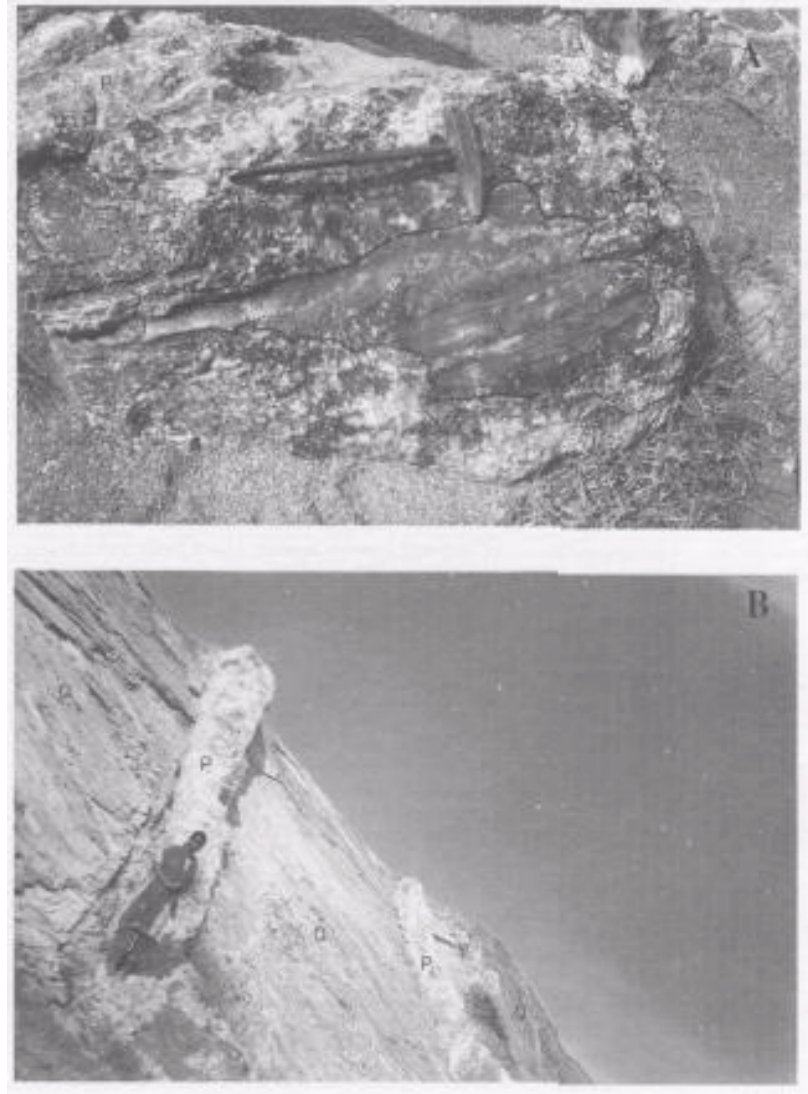

Figure 3 - (a) - Feldspar-rich pegmatite $(P)$ containing partially digested inclusion of altered amphibolite $(A)$. The pegmatite has concordant relation of planes of schistosity fillings that can be traced in micaschist encountered in close association with amphibolite exposed on the southern bank of the Kolar river, (b) - Series of dykes (two seen in this photograph) of pegmatite $(P)$ emplaced within the vertical tension joints in the thinly bedded micaceous qitartiites $(Q)$ near west end of the main quarry, Suradevi Hills, Kolar valley.

support that the pegmatite of present area under study have developed by the process of fractional crystallisation in a restricted or closed system as suggested for the pegmatites of Madhya Pradesh (Singh and Sharmal997, Babu 1993).

Genesis of Tourmaline Migration of some amount of fluids are not only instrumental for the formation of comparatively more muscovite in the wall rock mica-schist by the process of "Muscovitization" but "tourmalinization" of the original minerals (biotite and pink feldspar) in the pegmatites has also been suggested by Kilpady (1954).

On the basis of megascopic and microscopic characters, black tourmaline of two distinct varieties, namely schorlite and dravite have been identified (Kilpady 1954, Gwalani 1969). The coarse crystals of schorlite have abundant inclusions of muscovite (Fig. 5) and quartz; it also shows subgraphic intergrowths with quartz, and fractures filled by muscovite, microcline and quartz. The schorlite crystals are of earlier generation and they have been derived from original biotite either during pre-emplacement or at the time of emplacement of pegmatite.

The dravite variety of tourmaline is formed at latter stage by the pneumatolitic action on the pink feldspar during the post solidification stage of pegmatite. The conversion of feldspar (microcline/orthoclase) was largely effected by molecular diffusion process, and this process is similar to the process of formation of Luxullianite described by Wells (1956). During the replacement of pink feldspars by tourmaline lot of quartz was released and the various stages of alteration are observed. The massive irregular patches as well as well developed crystals, which often contain relict microcline, are obviously derived from the feldspar (Kilpady 1954)

SUMMARY AND CONCLUSION The coarse to very coarse granitic pegmatites of Koradi-Kolar sector show simple to complex 


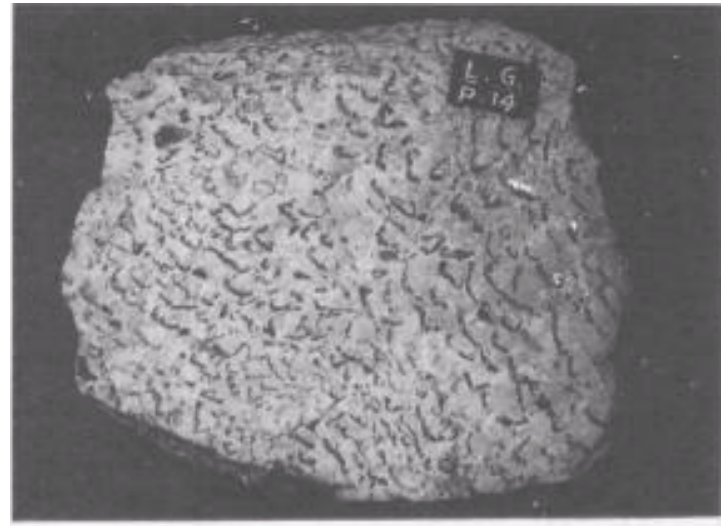

A

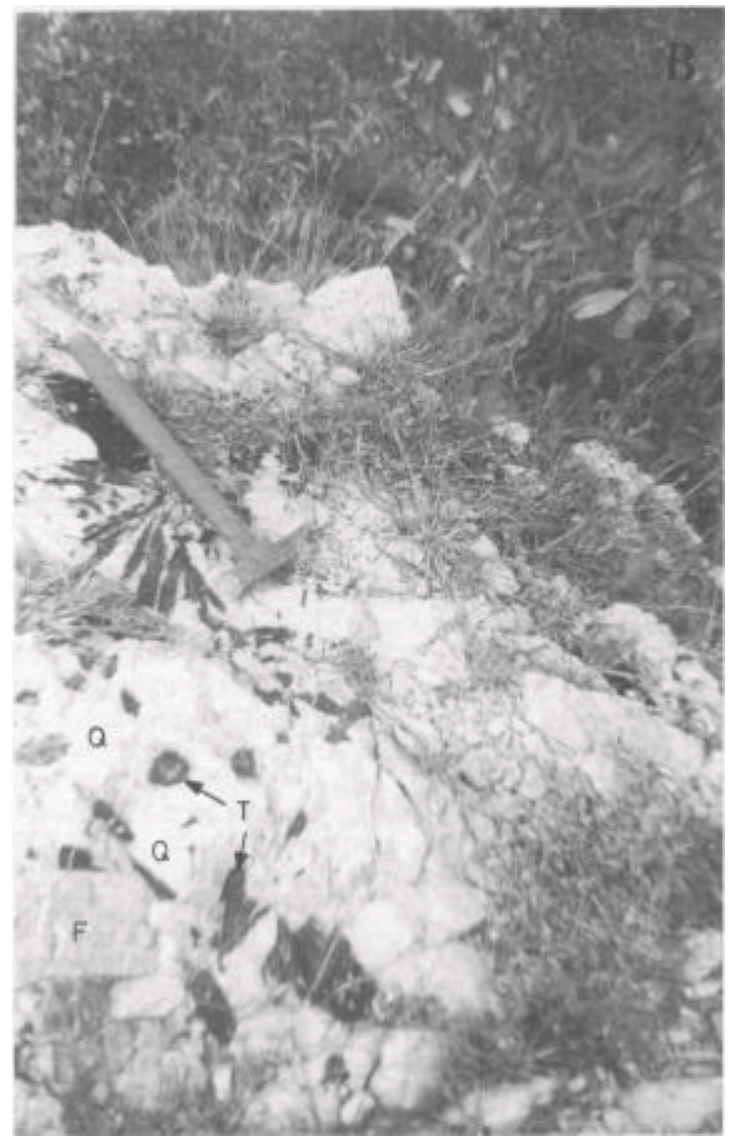

Figure 4 - (a) - Specimen (scale = half the natural size) of eutectic pegmatite showing graphic intergrowths of quartz and microcline. (b) - Dispersed crystals, patches and sheaves of black tourmaline (T) in the concordant pegmatite comprising mainly pink microcline feldspar $(F)$ and quartz $(Q)$. Locality: Kolar valley.

mineral assemblage (quartz, feldspar, mica, tourmaline, epidote, etc.). Most bodies are emplaced (concordant and discordant) within the schistose rock (mica-schist and amphibolites) along (a) bedding planes, (b) joint planes (c) fault planes and (d) contact of metasedimentary and metabasic (amphibolite) rocks. Deformation and metamorphism of rocks have taken place prior to the pegmatitic activity. However, post pegmatite folding (ptygmatic) and pinch-and-swell structure in aplitic pegmatite in the amphibolites are noticed locally.

The pegmatites occur mostly as swarms, and show variation in size (length $<1 \mathrm{~km}$, and width $<1 \mathrm{~m}$ to $15 \mathrm{~m}$ ) and shape (tabular, lenticular and vain like bodies). As mention above, variation is also observed in their mineralogy, and on the basis of this character, important pet-

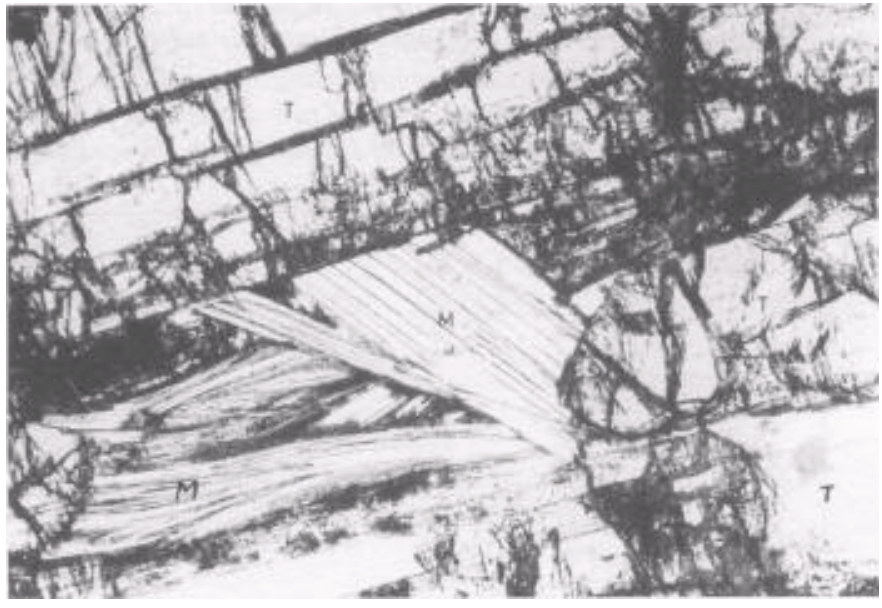

Figure 5 - Fractured tourmaline (T) plate contains a few coarse and rosette-shaped muscovite (M) inclusions that have somewhat radiating form. This photomicrograph of a portion of a large tourmaline crystal from quartz-pegmatite was taken under polarised light (x 32).

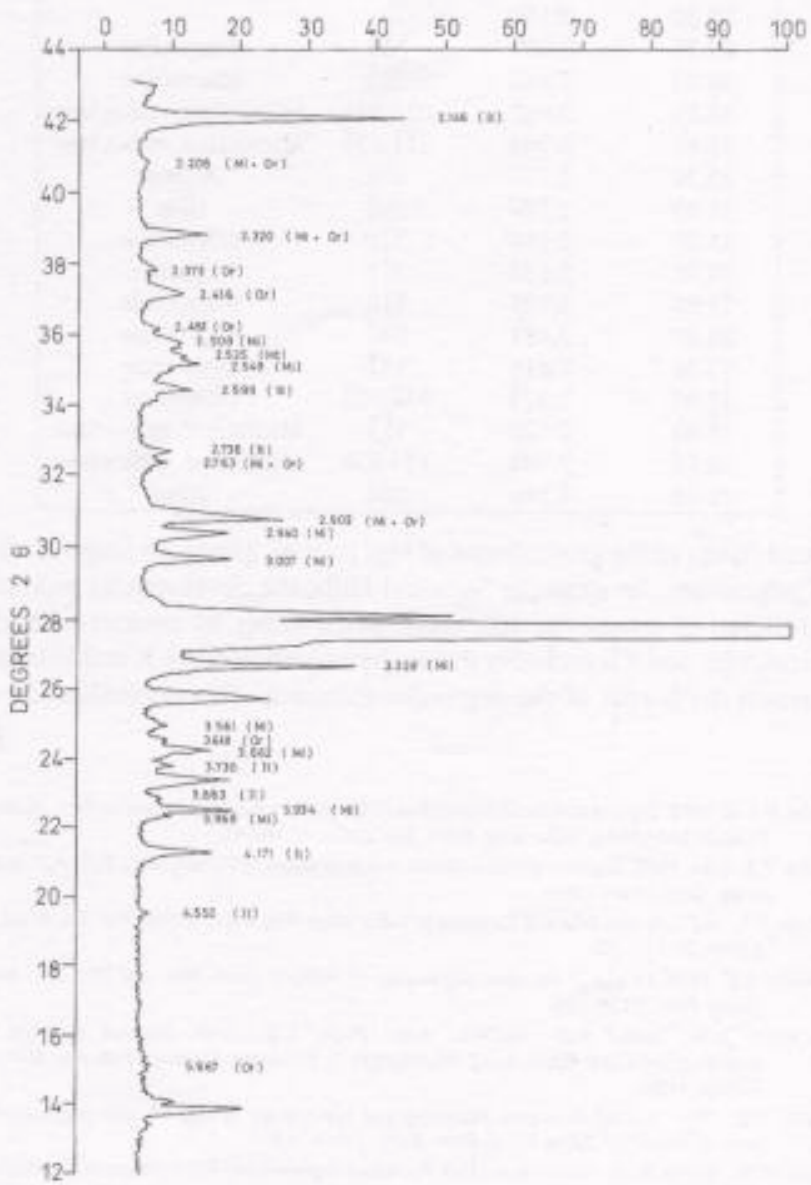

Figure 6 - X-ray diffractogram of feldspar-rich pegmatite containing microcline (Mi), orthoclase (Or), illite (II), ilmenite (It), and magnetite in the mineralogy. The XRD machine was set at $30 \mathrm{kV} / 20 \mathrm{~mA} / 2.5 \mathrm{~K} / \mathrm{la}$ for obtaining the diffractogram.

rographic associations observed in the pegmatites are microclinequartz with muscovite and/or tourmaline, eutectic quartz-microcline (graphic granite) and massive quartz-pegmatite with or without muscovite. Generally muscovite, quartz and tourmaline seem to have developed in two distinct generations. For example the muscovite of earlier generation forms books and the later crystals occur as dissemi- 
Table 2 - XRD Data (peak angle in degrees $2 \theta$ and the ' $d$ ' spacing) of the minerals of feldspar-rich pegmatite from Kolar valley, Nagpur district, Central India. References for converting the peak 2 Theta $(\theta)$ angles into the interplanar spacings (d) used are: Johnson $J r \&$ Vand (1968), Fang \& Bloss (1966); and Joint Committee on Powder Diffraction Standards, 1974.

\begin{tabular}{|c|c|c|c|}
\hline $\begin{array}{l}\text { Peak angle } \\
\text { in degree } \\
\text { ( } \theta) \text { theta }\end{array}$ & $\begin{array}{l}\text { Interplanar } \\
\text { spacing-d }\end{array}$ & $h k l$ & Mineral name \\
\hline 13.90 & 6.370 & - & -- \\
\hline 14.10 & 6.280 & - & .. \\
\hline 15.10 & 5.867 & $11 \mathrm{~T}$ & Orthoclase \\
\hline 19.50 & 4.552 & 110 & Illite \\
\hline 21.30 & 4.171 & 022 & Illite \\
\hline 22.40 & 3.968 & 11 & Microcline \\
\hline 22.60 & 3.934 & 1̄il & Microcline \\
\hline 22.90 & 3.883 & 113 & Illite \\
\hline 23.50 & 3.785 & $\ldots$ & $\cdots$ \\
\hline 23.85 & 3.730 & 102 & Ilmenite \\
\hline 24.30 & 3.662 & $13 T$ & Microcline \\
\hline 24.60 & 3.168 & $13 \bar{I}$ & Orthoclase \\
\hline 25.00 & 3.561 & $22 \mathrm{~T}$ & Microcline \\
\hline 25.80 & 3.453 & $\ldots$ & -- \\
\hline 26.70 & 3.338 & 220 & Microcline \\
\hline 27.70 & 3.220 & $\cdots$ & -- \\
\hline 28.20 & 3.164 & $\therefore$ & -- \\
\hline 29.70 & 3.007 & 131 & Microcline \\
\hline 30.40 & 2.940 & $22 \overline{2}$ & Microcline \\
\hline 30.80 & 2.902 & 022,041 & Microcline, orthoclase \\
\hline 32.40 & 2.763 & $3 \Pi_{1}, 13 \overline{2}$ & Microcline, orthoclase \\
\hline 32.70 & 2.738 & 104 & Ilmenite \\
\hline 34.50 & 2.599 & $20 \overline{2}$ & Illite \\
\hline 35.20 & 2.549 & $3 \overline{1} 0$ & Microcline \\
\hline 35.40 & 2.535 & 3TI & Magnetite \\
\hline 35.80 & 2.508 & 310 & Microcline \\
\hline 36.20 & 2.481 & 240 & Orthoclase \\
\hline 37.20 & 2,416 & $15 \mathrm{~T}$ & Orthoclase \\
\hline 37.90 & 2.373 & $33 \bar{T}, 20 \overline{3}$ & Orthoclase \\
\hline 38.80 & 2.320 & $11 \overline{3}$ & Microcline, orthoclase \\
\hline 40.85 & 2.208 & 151,330 & Microcline, orthoclase \\
\hline 42.10 & 2.146 & $20 \overline{6}$ & Illite \\
\hline
\end{tabular}

nated flakes in the groundmass of less coarser quartz. In larger bodies of pegmatites, for example Suradevi Hills, the development and concentration of muscovite has taken place along its contact with the micaschist, and it is probably due to the migration of $\mathrm{Al}, \mathrm{K}$ and volatiles towards the border of the pegmatite intrusion. This crystallisation of

Babu, P.V.R. 1993. Tin and rare mclal pegmatites of the Bastar - Koraput pegmatite Belt, Madhya Pradcsh and Orissa, India. Jour. Ceol. Sue. India, 42:180-90.

Babu, V.R. R.M. 1969. Temperature of Formation of pegmatites of Nellore Mica Belt, A.P. India. Econ.Geol. 64:66-71

Bhola, K.L. 1971. Atomic Mineral Deposits in Bihar Mica-Bell, Proc. Indian Nat. Sci. Acad. 37 A (No. 2): 145-168.

Biswas, S.L. 1929. Origin of the mica-pegmatites of Ncllorc. Ceol. Min. and Met. Soc. India Quart. Jour. 7:135-144.

Camcron. E.N.; Jahns. R.H.; McNair, A.H.; Page, L.R. 1949. Internal structure of granitic-pegmatites. Econ. Ceol. Monograph 2, Economic Geology Pub. Co. Urbana, Illinois, $115 \mathrm{p}$.

Datta, A.K. 1973. Internal Structure, Petrology and Mineralogy of calc-alkalinc pegmatites in parts of Rajasthan. Mem. Geol. Surv. India, 110:1-112.

Deer, W.A.; Howic, R.A.; Zussm/n, J. 1963. Rockforming Minerals Vol.4 (Framework silicates) 435p.

Eugstcr, H.P. \& Yodcr, H.S. 1954. Phlogopitc synthesis and stability range. Geochim. Cosmochim. Acta, 6:157-185.

Fang, J.H. \& Bloss, F.D. 1966.XKD Diffraction Tables, Southern Illinois University Press, Fcffir \& Simons, Inc. London \& Amsterdam.

Fermor, L.L. 1936. Mem. Geol. Surv. India 70:267-268.

Gwalani, L.G.; Rock, N.M.S.; Chang, W -J.; Fernandez, S.; Allcorc, C.J.; Prinshofer, A., (1993). Alkaline rocks and earbonalitcs of Amba Dongar and adjacent areas, Deccan Igneous province, Gujarat.India: Geology, petrography and petrochemistry. Mineral Petrol Al:219-253.

Gwalani, L.G. \& Dalai, V .P., 1988. Environmental Geologic Study of Nagpur City (Maharashlra, India) and its vicinity. The Compass, The Earth-science Jour. Sigma Gamma Epsilon, U.S.A. 65(2): 124-132.

Gwalani, L.G. 1969. Geology of the area north of Koradi, Nagpur district,India : M.Sc. Dissertation, Nagpur University, Unpubl.,73p.
Table 3 - Chemical analyses of the pink-feldspars and muscovite (tr $=$ traces, $n d=$ not detected) GF-1 \& GF-2: Microcline from pegmatites, Kolar Valley, Nagpur district, India.(2)Deeret al. 1963: Microcline microperthite, Graphite-bearing pegmatite, Bihar state, India. (3) CM-6: Muscovite from pegmatite, Kolar Valley, Nagpur district, India.

\begin{tabular}{|l|r|r|r|r|}
\hline Sample & \multicolumn{1}{c|}{ GF-1 } & GF-2 & Deer et al. (1963) & GM-06 \\
\hline $\mathrm{SiO}_{2}$ & 60.05 & 61.04 & 64.26 & 44.68 \\
$\mathrm{TiO}_{2}$ & 0.10 & $\mathrm{Tr}$ &.- & 0.54 \\
$\mathrm{Al}_{2} \mathrm{O}_{3}$ & 21.20 & 19.92 & 19.72 & 32.82 \\
$\mathrm{Fe}_{2} \mathrm{O}_{3}$ & $\mathrm{Tr}$ & $\mathrm{Nd}$ & 0.10 & 3.34 \\
$\mathrm{MnO}$ & $\mathrm{Tr}$ & $\mathrm{Nd}$ & -- & 0.07 \\
$\mathrm{MgO}$ & 0.13 & 0.96 & $\mathrm{Tr}$ & 0.72 \\
$\mathrm{CaO}$ & $\mathrm{Tr}$ & $\mathrm{Tr}$ & 0.31 & $\mathrm{Nd}$ \\
$\mathrm{Na}_{2} \mathrm{O}$ & 3.11 & 2.50 & 2.28 & 0.72 \\
$\mathrm{~K}_{2} \mathrm{O}$ & 15.80 & 16.31 & 13.20 & 11.34 \\
$\mathrm{H}_{2} \mathrm{O}$ & $t r$ & $t r$ & 0.18 & 5.46 \\
Total & 100.39 & 100.73 & 100.05 & 99.69 \\
\hline
\end{tabular}

muscovite, which is of later generation, is in preference to feldspar, and is due to the presence of higher volatile contents in the fluids. The earlier quartz is strongly deformed while the later occurs as veins of variable size and length. Black tourmaline belonging to two distinct types, schorlite and dravite are of different origin. The schorlite crystals have been derived from original biotite (either pre-emplacement or during emplacement) where as dravite appears to belongs to a second or later generation and is derived from pink feldspar by the late process of pneumatolysis. Field evidences have indicated that the influx of pegmatitic fluids sometimes associated, with structural deformation of the earlier rock units of Sausar Group (Chorbaoli, Junewani and Bichua Formations) and subsequently these fluids occupied the fractures and other planes of weakness (foliation: bedding and schistosity) in the host rocks. From the optical, XRD and mineral chemistry, it has been concluded that the pegmatites of Koradi-Kolar sector are mostly potassic in composition.

Acknowledgements The XRD analyses were carried out at the Wichita State University (USA) and VPD thanks Dr. Daniel F. Merriam for providing help and XRD facilities in the Geology Department.

Mineral analyses were carried out at the university of Madrid (Spain), and LGG thanks Miss Maribel Sevillano for the assistance during the analytical work. Grateful thanks are also due to Prof. A.N. Sial of Fedeal University of Pernambuco (Brazil) for inviting LGG for the presentation of this paper at the ISGAMII, Salvadar meeting, to the CNPa authorities for providing travel assistance. This is NEG-LABISE's (Geology Departament UFPE, Recife, Brazil) contribution n ${ }^{\circ} 161$.

\section{References}

Gwalani, L.G.; Choudhary, N.KJJ; Dalai, V.P.; Patil, S.; Kesarwani, A.; Khan, P.M.; Khor K.V. 1997. Geological Field Excursion around Nagpur. Quart. Jour. Geol. Assoc. \& Research centre, Balaghal, India, 5:74-80.

Haidengcr,W.,1845. Handbuch der bestimnenden mineralogic, Wicn, $585 \mathrm{p}$.

Holland, T.H. 1902, the mica deposits of India, Mem. Geol Surv. India 34:PI2.

Johnson Jr, G.G. \& Vladimir, V. 1968. KWIC Guide to the Powder Diffraction, ASTM Publications, PD1S-18K, USA

Joint Committee on Powder Diffraction SlandartS 1974. Selected Powder Diffraction Data for Minerals. Published by U.S.A. Joint Comm. Powder Diffraction Standards, First Edition.

Kilpady, S. 1954. A tourmaline pegmatite from Koradi, Central provinces. Jour. University Geol, Soc., Nagpur, India, 1:1-7.

Kumar, R. 1992. Fundamentals of Historical Geology and Stratigraphy of India. Wilcy Eastern Ltd., New Delhi. $254 \mathrm{p}$

Lamba. V.J.S. \& Khanna, V.K. 1981. Characteristic features of tin-bearing rare met al pegmatites of Konla Tahsil, Bastar Dist, M.P. Bull. Indian Geol. Assoc., 14(2): 151-154.

Landcs, K.K.,1933. Origin and classification of pegmatites, Amcr. Min., 18:33-56, 95-103.

Quirkc, T. \& Kramers, HE. 1943. Pegmatite crystallisation, Amer. Min 28.571-580.

Ramaswamy, C.; Deshpandc, M.L.; Murthy, K.S.; Jaiswar, H.P.; Jcsani, R.S. 1976. Tin-bearing pegmatites of Baslar, M.P. Geol. Surv. India, Spl. Pub. No. 3:185-189,

Sarkar, S.N.; Polkanov, A.A.; Gcrling, E.K.; Chukrov, F.V. 1967. Precambrian gcochronology of Nagpur-Bhandara-Drug, India, Geol. Mag. 104:525-549.

Singh, Y. \& Sharma, D.S. 1997. Geology of Tantalitc pegmatite from Belangi, Surguja District, Madhya Pradesh, India, Jour. Geol. Soc. India, 49:427-432.

Soman, K.; Nagir.N.G.K.; Dru/hnin A.V. 1986. Chrysobcryl pegmatites of South Kerala and their metallogenic implications. Jour. Geol. Soc. India, 27:411-418.

Wells, MK. 1946. A contribution to the study of Luxullianitc. Min Mag., 27:186-194.

West, W.D. 1933. Record Geol. Surv. India 67:344-356.

Manuscrito A-1056

Recebiclo em 25 de Janeiro de 1998 Revisao dos autores em 30 de setembro de 1998 Revisao aceita em 02 de outubro de 1998 